\title{
Temporal variations of organic matter fractions of different lability in an Entic Haplustoll
}

\author{
Variaciones temporales de fracciones de materia orgánica de diferente labilidad en un Entic \\ Haplustoll \\ Variaçôes temporais de fraçôes da matéria orgânica de diferente labilidade num Entic \\ Haplustoll
}

\section{AUTHORS}

Iturri L.A.@,1,2 antonelaiturri@conicet.com

\section{Hevia G. G. ${ }^{2}$}

Díaz-Raviña M. ${ }^{3}$

Buschiazzo D. E. . $^{1,2} 4$

Received:23.01.2017 | Revised: 11.04.2017 | Accepted:24.04.2017

\section{ABSTRACT}

Stable and labile soil organic compounds play different roles in the soil. It is a question of how far soil organic matter (SOM) fractions with different labilities vary as a function of climatic and management conditions. In order to answer this question stable (organic $\mathrm{C}-\mathrm{C}-$, total $\mathrm{N}-\mathrm{N}$-, organic $\mathrm{P}-\mathrm{Po}^{-}$), and labile SOM fractions (total carbohydrates - $\mathrm{CHt}$ - and hot water soluble carbohydrates $-\mathrm{CHw}^{-}$) were measured monthly for two years in the $10-\mathrm{cm}$ soil top-layer of an Entic Haplustoll, under conventional tillage (CT), vertical tillage (VT) and no-till (NT). Results showed that contents of all analyzed organic fractions were higher in NT than in VT and CT in almost all sampling dates. All organic compounds were less variable with time in NT and VT than in CT, in agreement with the smaller soil disturbance of NT and VT compared to CT. The more labile fractions varied as a function of short term changes in the climatic conditions, mainly temperature. Under soil disturbing tillage systems, the most stable fractions tended to decrease and the more labile to increase with time. This was attributed to the transformation of the more stable into the more labile fractions, possibly due to the disruption of aggregates produced by tillage that favored SOM mineralization. Po was the less variable compound, even under the most disturbing tillage conditions. The quotients $\mathrm{C} / \mathrm{N}, \mathrm{CH} / \mathrm{C}$ and $\mathrm{CHw} / \mathrm{C}$ evolved similarly in all tillage systems, indicating that that tillage systems change the amount but not the quality of SOM. La Pampa, Argentina.

${ }^{2}$ National University of La Pampa (UNLPam). cc 300, 6300 Santa Rosa La Pampa, Argentina.

${ }^{3}$ Soil Biochemistry Department, Institute for Agrobiological Research of Galicia of CSIC. cc 122, 15780 Santiago de Compostela, Spain.

${ }^{4}$ National Institute for Agricultural Technology (INTA), Anguil Experimental Station. cc 11, 6326 Anguil, Argentina.

\section{RESUMEN}

Los compuestos estables y lábiles de la materia orgánica juegan papeles diferentes en el suelo. Se desconoce cómo las fracciones de materia orgánica del suelo (SOM) de diferente labilidad varían en función de las condiciones climáticas y de manejo. Para dar respuesta a esta cuestión se midieron mensualmente a lo largo de dos años las fracciones estables ( $C$ orgánico - $C-, N$ total- $N-, P$ orgánico-Po-), y las fracciones lábiles (carbohidratos totales -CHt-y carbohidratos solubles-CHw-) en los primeros $10 \mathrm{~cm}$ de un Entic Haplustoll, bajo labranza convencional (CT), labranza vertical (VT) y siembra directa (NT). Los resultados mostraron que los contenidos de todas las fracciones de la materia orgánica analizadas fueron mayores en NT que en VT y CT en la mayoría de las fechas de muestreo. Todos los compuestos orgánicos fueron menos variables con el tiempo en NT y VT que en CT, de acuerdo con la menor alteración del suelo en NT y VT que en CT. Las fracciones más lábiles variaron en función de los cambios a corto plazo en las condiciones climáticas, principalmente la temperatura. Bajo sistemas de labranza que incluyeron perturbación del suelo, las fracciones más estables tendieron a decrecer y las más lábiles a aumentar con el tiempo. Esto fue atribuido a la transformación de las fracciones más estables en fracciones más lábiles, posiblemente debido a la ruptura de los agregados producida por la labranza que habría favorecido la mineralización. El Po fue el componente menos variable, aún bajo condiciones de labranza con alta perturbación del suelo. Las relaciones C/N, $\mathrm{CHt} / \mathrm{C}$ y $\mathrm{CHw/C}$ evolucionaron de forma similar en todos los sistemas de labranza, indicando que los sistemas de labranza cambian la cantidad pero no la calidad de la SOM. 


\section{RESUMO}

Os compostos estáveis e lábeis da matéria orgânica têm papeis diferentes no solo. A forma como as fraçôes da matéria orgânica do solo (SOM) com diferente labilidade variam em função das condiçôes climáticas e das condiçôes de maneio do solo é pouco conhecida. Para responder a esta questão mediram-se mensalmente, ao longo de dois anos, as fraçôes estáveis ( $C$ orgânico-C-, $N$ total- $N-, P$ orgânico-Po-), e as fraçôes lábeis da $S O M$ (bidratos de carbono totais CHt-e hidratos de carbono solúveis - CHw-) na camada dos primeiros $10 \mathrm{~cm}$ de um Entic Haplustoll, submetido a lavoura convencional (CT), lavoura vertical (VT) e plantio direto (NT). Os resultados mostraram que os teores de todas as fraçôes da matéria orgânica analisadas eram maiores no NT do que no VT e no CT na maioria das datas de amostragem. Em função do tempo, as concentraçôes de todos os compostos orgânicos eram menos variáveis em NT e VT do que em CT, o que está de acordo com a menor perturbação do solo em NT e VT comparada com a do CT. As fraçôes mais lábeis variaram em função das alteraçôes de curto prazo nas condiçôes climáticas, nomeadamente a temperatura. Em condiçôes de lavoura de maior perturbação do solo, as fraçôes mais estáveis tenderam a diminuir e as mãos lábeis a aumentar com o tempo. Este facto foi atribuído à transformação das fraçôes mais estáveis em fraçôes mais lábeis, possivelmente devido à quebra dos agregados produzida pela lavoura, o que teria favorecido a mineralização da SOM. O Po foi o componente menos variável, mesmo sob condições de lavoura com alta perturbação do solo. As relaçôes $\mathrm{C} / \mathrm{N}, \mathrm{CH} t / \mathrm{C}$ e $\mathrm{CH}$ w/C evoluíram de maneira semelhante em todos os sistemas, indicando que os sistemas de lavoura mudam a quantidade mas não a qualidade da SOM.

\section{Introduction}

SOM compounds of different labilities can be affected by climatic and management conditions differently. The stable SOM compounds are indexes of soil quality and productivity in the long term (Gregorich et al. 1994) and are variably useful to assess the general health status of the soil (Inzaurralde et al. 2001; Lal 2004). Recently, many studies have been conducted regarding the relationships between SOC and climate and land use changes, especially regarding SOC as a source or sink for greenhouse gases that influence the global climate (Conen and Leifeld 2014; Davidson and Janssens 2006; Leifeld 2006; Fröhlich-Nowoisky et al. 2012; Oertel et al. 2016; Post and Kwon 2000).

The more labile compounds change on daily or weekly basis, as their biological decomposition kinetics depend on short-term changing climatic and management conditions like soil temperature, water contents or the amount of plant residues incorporated into the soil by tillage operations (Díaz-Zorita et al. 2002; Haynes 2005; Soon et al. 2007). The most labile fractions have been frequently found to be responsible of the availability of nutrients for plants or the formation of stable macroaggregates, which contributes, for example, to the resistance of the soil against wind or water erosion (Gregorich et al. 1994; Buschiazzo et al. 1999b; Hevia et al. 2003; Haynes 2005).

The temporal variation of the more stable SOM forms is lower than that of the more labile fractions (Gregorich et al. 1994; Haynes 1999; Martín et al. 2011). This was demonstrated mainly for soils under similar management and crops conditions, like those analyzed by Haynes (1999) who studied the variability of labile organic matter fractions in no-till systems. However, less information is available on the combined effect of variable climatic conditions, different tillage systems and crop type on organic matter fractions of different labilities. 
It is largely known that tillage systems produce soil conditions that may differently affect the stable and labile soil organic matter fractions. No-till systems, due to the low soil disturbing conditions, show normally more stable soil temperatures and water contents than tillage systems with high soil disturbing conditions. Notill systems show also lower mineralization rates of organic compounds than tillage systems with high soil disturbing conditions (Buschiazzo et al. 1999a; Díaz-Zorita et al. 2002).

The objective of this study was to evaluate the temporal variations of stable and labile organic matter fractions in a soil submitted to different tillage systems.

\section{Materials and methods}

This study was conducted at a long-term experimental site located in the Agronomy Faculty of The National University of La Pampa, Argentina (36 $46^{\circ}$ 'S latitude and $64^{\circ} 16^{\prime} \mathrm{W}$ longitude, $165 \mathrm{~m}$ above sea level) in the Semiarid Pampean Region. The soil at the study site is classified as an Entic Haplustoll with a surface A horizon of $18 \mathrm{~cm}$ and a petrocalcic horizon present at $120 \mathrm{~cm}$ - depth (A-AC-C-Ck horizon sequence). The parent material of the soil is of aeolian origin, and it is called Pampa loess (INTA et al. 1980; Moscatelli and Puentes 1996).

The mean annual air temperature of the site was $14.5^{\circ} \mathrm{C}$. Averaged rainfall for the period 1913 to 2000 was $664 \mathrm{~mm}$ and increased during 19702000 to $760 \mathrm{~mm}$, with a usual interannual variability of 400 to $1000 \mathrm{~mm}$ and $75 \%$ of the events occurring in spring and summer. The total rainfall for the year 2002 was $748 \mathrm{~mm}, 377.7 \mathrm{~mm}$ for 2003, and 707.9 $\mathrm{mm}$ for 2004. The climatic data were recorded via an automatic meteorological station located $1100 \mathrm{~m}$ away from the experimental site. The mean monthly precipitation (MP), the inverse mean monthly temperature (1/MMT) as well as the quotient between them (Lang et al. 1920) were used to correlate some soil properties with the climatic conditions.
The long-term experimental site has been in operation since 1996. The tillage experiment was installed with the following three treatments, each on a 10 ha field: 1) no-till (NT), consisting of the chemical control of weeds with glyphosate and 2-4 $\mathrm{D}$, and the seeding of crops with no-till seeders, 2) conventional tillage (CT) where the primary tillage is done with a disker (a disk plow $3 \mathrm{mo}$ ) at 15- to 18 $\mathrm{cm}$ - depth plow, and the secondary tillage practices with an offset disk, and 3) vertical tillage (VT) where the primary tillage practices are made with chisels and the secondary with an offset disk. The crop sequence in all tillage systems was the same as those widespread in the semiarid Pampean region: maize (Zea mays) sown in November 2001, sunflower (Helianthus annus) sown in November 2002 (failed due to a drought), soybean (Glycine max) sown in December 2002 (not harvested due to a drought), sorghum (Sorghum $\mathrm{sp}$ ) sown in November 2003, and fallow until winter 2004. Triplicate $5 \mathrm{~kg}$ samples of the topsoil $(0-10 \mathrm{~cm})$ were taken per subplot -i.e. from the same three randomly selected and geographically referenced $10 \mathrm{~m}^{2}$, in approximately $10 \mathrm{~m}$ - intervals within each tillage system, on the following dates: October 11 2002, November 11 2002, December 16 2002, February 19 2003, April 29 2003, June 10 2003, October 6 2003, November 24 2003, December 29 2003, February 13 2004, March 19 2004, April 15 2004, May 17 2004, June 16 2004, August 2 2004, September 6 2004, and October 212004. Despite the lack of true replications, the experiment was used for testing the interactive effects of tillage systems and sampling time on SOM fractions of different labilities, because it was the only available tillage experiment in the Semiarid Pampean Region of Argentina. However, the sampling area showed a high areal homogeneity of soil texture. According to Gili (2012) in a study performed during the last decade over the same long term experimental site, the areal variability of silt and clay contents of the A horizon was lower than $5 \%$ within the 10 -ha field.

Table 1 shows that the textural composition of the soil did not differ between tillage systems, which demonstrates that the parent material was homogeneous. It is known that the summation of silt and clay regulates the quantitative and qualitative SOM contents of the studied soils (Buschiazzo 2006), therefore it can be assumed that SOM changes in the quantitative and qualitative SOM contents during the 2 year study period were produced exclusively by the accumulated effect 
Table 1. Main soil properties (A-horizon) at experiment start

\begin{tabular}{lcccc} 
Tillage system & Clay & Silt & Sand & Texture \\
& \multicolumn{3}{c}{$\mathrm{g} 100 \mathrm{~g}^{-1}$ soil } \\
VT & 12.85 & 20.84 & 56.67 & Sandy loam \\
\hline NT & 15.52 & 21.69 & 54.25 & Sandy loam \\
\hline CT & 12.55 & 21.15 & 59.67 & Sandy loam \\
\hline
\end{tabular}

Values are means of triplicate soil samples. VT: vertical tillage, NT: no-till, CT: conventional tillage.

of tillage operations in interaction with crops sequences and climatic conditions. This allowed us to compare all studied parameters between tillage systems and sampling dates by means of ANOVA. LSD multiple comparison tests were performed to test differences between tillage systems. Simple regression analysis was used to test relationships between all the studied variables were assessed. Statistical analyses were performed at a 0.05 probability level using Microsoft Excel and InfoStat/ Profesional version 1.1 (Di Rienzo et al. 2002). The 0-10 cm sampling depth was chosen considering that most of changes of SOM contents in the semiarid Pampean region occur within this depth (Bono et al. 2008).

After homogenization, soil samples were air-dried and sieved through a $2 \mathrm{~mm}$ sieve. The 2-mm sieve was chosen because according to Hevia et al. (2003), the SOM of soils of the studied region is mainly accumulated (58\%) in the 100-2000 $\mu \mathrm{m}$ sized aggregates, and to a lesser extent $(36 \%)$ in $<100 \mu \mathrm{m}$ aggregates and in water-floatable organic matter $(5 \%)$.

Particle size distribution was determined by the combined wet sieving and pipette method (Schlichting et al. 1995) and $\mathrm{CaCO}_{3}$ /inorganic carbon contents by the pressure-calcimeter method (Nelson 1982), both only at the beginning of the experiment as we considered that its contents remained constant. The $\mathrm{pH}$ (1:2.5 soil:water by McLean 1982) was monitored throughout the experiment and at each sampling.

Organic carbon contents (C) were determined monthly by the Walkley and Black method (1934), as well as total nitrogen ( $\mathrm{N}$ ) by the semimicro Kjeldahl procedure (Bremner and Mulvaney 1982) and total $(\mathrm{Pt})$ and inorganic $(\mathrm{Pi})$ phosphorus by calcination (ignition of soil at $550{ }^{\circ} \mathrm{C}$ ) and no calcination followed by $1 \mathrm{~mol} \mathrm{dm}^{-3} \mathrm{H}_{2} \mathrm{SO}_{4}$ extraction (Kaila 1962), respectively. $P$ was determined in each extracting solution by means of the ascorbic acid and ammonium molybdate blue method (Schlichting et al. 1995) and the organic $P(P)$ was calculated by difference between $\mathrm{Pt}$ and $\mathrm{Pi}$ (Kaila 1962). Soil carbohydrate contents $(\mathrm{CHt})$ were estimated colorimetrically after extraction by hotacid hydrolysis (Pugget et al. 1999) and soluble carbohydrates $(\mathrm{CHw})$ by hot-water hydrolysis (Doutre et al. 1978) (soluble carbohydrates, CHw) using standard methods. Briefly, $\mathrm{CHt}$ determination consisted of the hydrolysis of $1 \mathrm{~g}$ soil with $5 \mathrm{~mL}$ of $\mathrm{H}_{2} \mathrm{SO}_{4} 12 \mathrm{~mol} \mathrm{~L}^{-1}$ at room temperature. After 12 hours distilled water was added up to $100 \mathrm{~mL}$ and heated at $100{ }^{\circ} \mathrm{C}$ for 5 hours. CHw determination consisted on the hydrolysis of $1 \mathrm{~g}$ soil with $10 \mathrm{~mL}$ distilled water at $80{ }^{\circ} \mathrm{C}$ for 24 hours (Pugget et al. 1999). Both extracts were finally obtained by centrifugation and filtration and contents of the hydrolyzed saccharides was determined by means of the anthrone method (Doutre et al. 1978). All measurements were performed in duplicate. Relationships between total organic carbon and total nitrogen ( $\mathrm{C} / \mathrm{N}$ ratio) and total and soluble carbohydrates contents and total organic carbon ( $\mathrm{CH} / \mathrm{C}$ and $\mathrm{CHw} / \mathrm{C}$, respectively) were calculated for each tillage systems in each sampling time.

In order to express the contents of all compounds on volume basis $\left(\mathrm{kg} \mathrm{ha}^{-1}\right)$, bulk density data of the topsoil $(0-10 \mathrm{~cm})$ was used. Such data were obtained from quintuplicate bulk density measurements made by 
means of the cylinder method every fifteen days along all the sampling period in each tillage system. By means of simple ANOVA it was demonstrated that no significant differences in bulk density $(P>0.10)$ existed between sampling dates within each tillage system. Thus, the following bulk densities were considered for calculations: $1.040 \mathrm{Mg} \mathrm{m}^{-3}$ for $\mathrm{VT}, 1.169 \mathrm{Mg} \mathrm{m}^{-3}$ for NT and $1.045 \mathrm{Mg} \mathrm{m}^{-3}$ for CT instead of an equivalent soil mass basis.

\section{Results}

Figure 1 shows that the averaged $\mathrm{C}$ contents of the two years sampling period varied between 13,364 and $22,651 \mathrm{~kg} \mathrm{ha}^{-1}, \mathrm{C}$ contents of NT being higher than those of both CT and VT for all sampling dates $(P<0.05)$.

C contents were more variable with time in CT $(\mathrm{CV}=11 \%)$ than in VT and NT $(\mathrm{CV}=7 \%$ and $6 \%$, respectively).

C contents in CT, NT and VT evolved similarly between September 2002 and October 2003, although they were more variable during 2004 . In this year, $\mathrm{C}$ contents also behaved in the same way in the three tillage systems, increasing towards summer and decreasing towards winter.

The interaction date $x$ tillage and the date and tillage factors were highly significant for $C$ contents $(P<0.0001)$. Due to this interaction, the contribution of both variables to the total C variability was $51.4 \%$, whereas the random factor (date) only contributed $26.2 \%$. This indicates that a strong interactive effect of tillage and sampling date on $\mathrm{C}$ contents fluctuations existed.

C contents did not correlate with any climatic variable, i.e. the mean monthly precipitation and the mean monthly temperature indicating that tillage rather than environmental conditions had the greatest incidence on $\mathrm{C}$ variability.
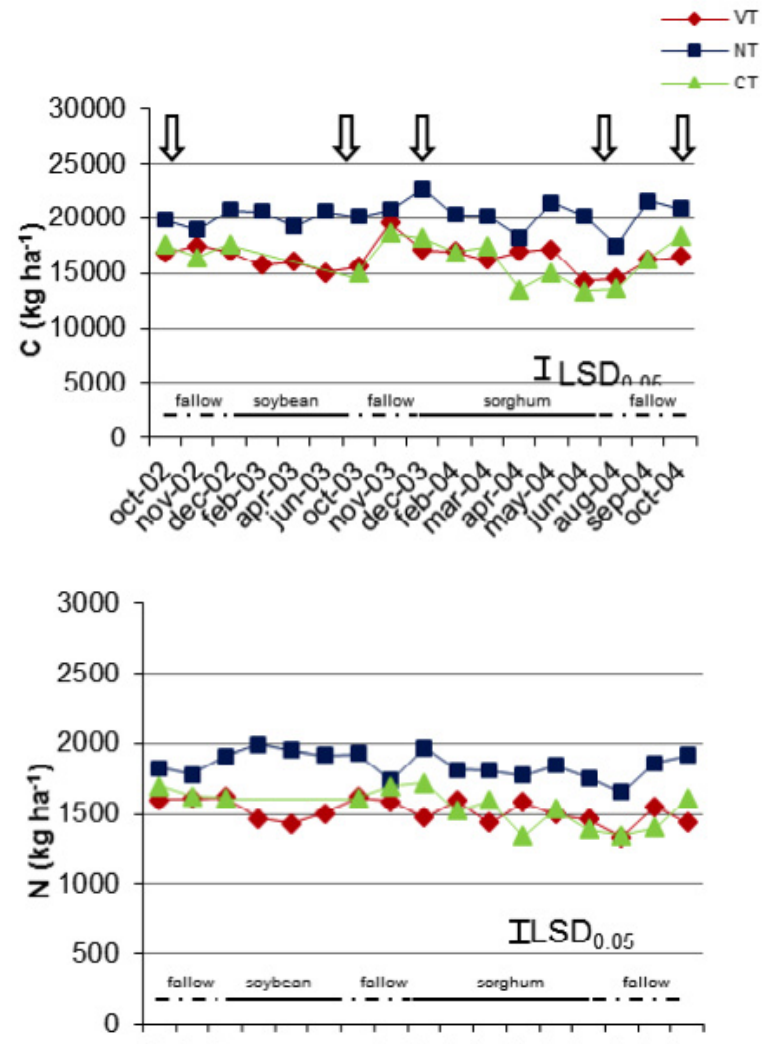

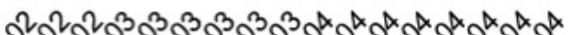

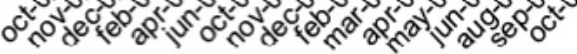

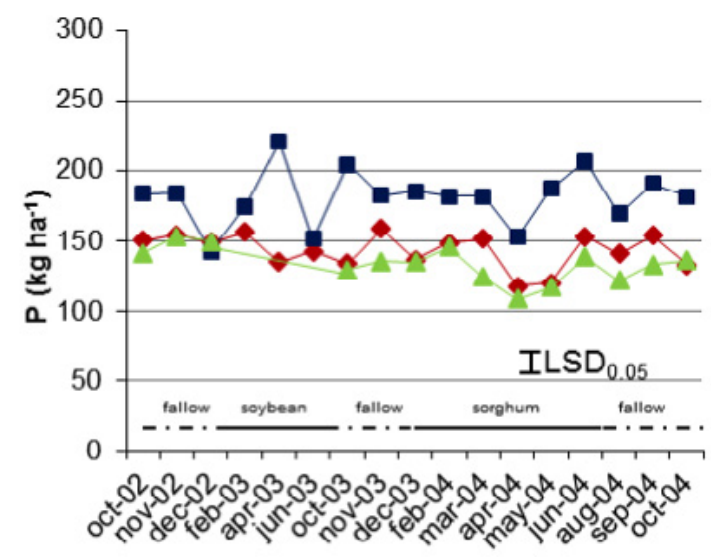

Figure 1. Variations of a) total carbon (C), b) total nitrogen $(\mathrm{N})$ and $\mathrm{c}$ ) organic phosphorus (Po) in vertical tillage (VT), no-till (NT) and conventional tillage (CT). Arrows indicate a tillage practice.

$\mathrm{N}$ contents (Figure 1) varied between 1,339 and $1,995 \mathrm{~kg} \mathrm{ha}^{-1}$, with the averaged contents being higher in NT than in the other two tillage systems for most of sampling dates $(P<0.05)$. 
The variability of $\mathrm{N}$ was higher $(\mathrm{p}<0.05)$ in CT ( $\mathrm{CV}=8 \%)$ than in VT and NT (CV $=5 \%$ in both), particularly due to variations occurred during the second sampling year.

$\mathrm{N}$ increased in NT and decreased in VT and CT during winter. Towards summer, a small increase occurred in NT while it remained constant in time in both VT and CT. In 2004, N had similar temporal variations than in the previous year in all tillage systems.

The interaction date $x$ tillage and the sources of variation date and tillage was highly significant for $\mathrm{N}$ contents $(\mathrm{P}<0.0001)$. The variability of $\mathrm{N}$ contents due to the interaction was $58 \%$ and the date factor contributed $27 \%$. These results show that a strong combined effect of type of tillage and sampling time over $\mathrm{N}$ total variability existed.

$\mathrm{N}$ did not correlate with any climatic variable and its contents over time showed similar fluctuations to $\mathrm{C}$. The similar behaviour of $\mathrm{N}$ and $\mathrm{C}$ was confirmed by a positive correlation between both variables: $r=0.93$ in $\mathrm{CT}, r=0.63$ in VT and $r=0.59$ in NT ( $P<0.001$ in all cases $).$

$P$ contents (Figure 1) varied between 108 and $220 \mathrm{~kg} \mathrm{ha}^{-1}$, with the averaged contents being higher in NT than in the other two tillage systems in most of sampling dates $(P>0.05)$. $P$ temporal variation ordered as follows: NT $(\mathrm{CV}=11 \%)>$ CT $(\mathrm{CV}=9 \%)>$ VT $(\mathrm{CV}=8 \%)$. Such variations were similar during both sampling years.

In the three tillage systems, the highest and the lowest $P$ values were, respectively, those of December 2002 and June 2003. The interaction date $x$ tillage and the sources of variation of these both variables were highly significant $(P<0.0001)$ for $P . P$ total variability due to the interaction was $35.7 \%$ and $30.2 \%$ attributed to the date factor. This shows that both the interaction and the sampling time contributed to the $P$ variability in a similar way.

P temporal variation did not correlate with any climatic variable, but it correlated positively with $C(r=0.79, P<0.001)$, and $N(r=0.78$, $P<0.001)$ in CT $(r=0.53, P<0.001)$ and only with $\mathrm{N}$ in $\mathrm{VT}(r=0.29, \mathrm{P}<0.05)$.

Figure 2 shows that $\mathrm{CHt}$ contents varied between 1,007 and $2,280 \mathrm{~kg} \mathrm{ha}^{-1}$, being, on average, higher in NT than in the other two tillage systems for almost all dates.

$\mathrm{CHt}$ variability along the two sampling years did not show remarkable differences between tillage systems, the variation coefficient being $20 \%$ in NT, $18 \%$ in VT and $15 \%$ in CT. Such variations were higher than those for $\mathrm{C}$.
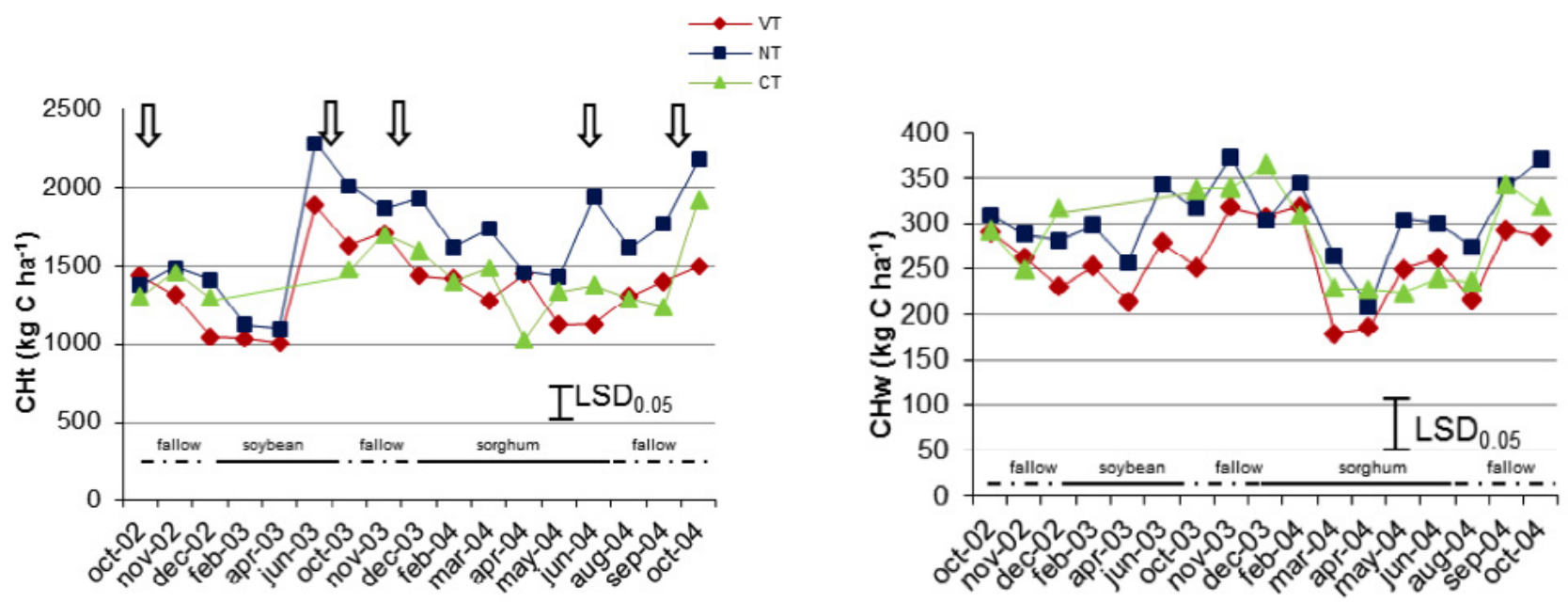

Figure 2. Variations of a) total carbohydrates $(\mathrm{CHt})$ and $b$ ) hot water extractable carbohydrates $(\mathrm{CHw})$ in no till (NT), vertical tillage (VT) and conventional tillage (CT). Arrows indicate a tillage practice. 
$\mathrm{CHt}$ contents had similar evolution trends during the 2 sampling years in all tillage systems, decreasing towards the winter and summer.

The interaction date $x$ tillage and the sources of variation of these both variables were highly significant $(P<0.0001)$ for $\mathrm{CHt}$. Similar to $\mathrm{C}$, the total variability for $\mathrm{CHt}$ due to the interaction was high $(50 \%)$, which shows that $\mathrm{CHt}$ was highly conditioned by the combined effect of type of tillage and sampling time. The random factor (date) contributed $32 \%$ to $\mathrm{CHt}$ variability.

$\mathrm{CHt}$ contents correlated positively with $\mathrm{C}$ in the three tillage systems. In CT the correlation was highly significant $(r=0.71, P<0.001)$ and significant in VT $(r=0.34, P<0.05)$ and NT $(r=0.37, P<0.05)$. This correlation indicates that both soil properties $\mathrm{C}$ - and $\mathrm{CH}$ t-contents had similar evolution trends in time, particularly in the conventional system (CT).

$\mathrm{CHt}$ contents correlated significantly with the inverse of the monthly mean temperature (1/MMT) in VT and NT ( $P<0.05$ in both). CHt did not show correlations: neither with the monthly rainfall (MP) nor with the MP/MMT quotient in any tillage system. Nevertheless, $\mathrm{CHt}$ showed highly significant correlations with $\mathrm{N}$ in CT $(r=0.66, P<0.001)$ and significant correlation in VT $(r=0.38, P<0.01)$ but not in NT $(P>0.05)$.

$\mathrm{CHw}$ contents (Figure 2) varied between 179 and $374 \mathrm{~kg} \mathrm{ha}^{-1}$, being higher in NT than in CT and VT on most of the sampling dates $(P<0.05)$.

$\mathrm{CHw}$ variability was higher in $\mathrm{CT}$ and VT (CV $16 \%$ in both) than in NT (CV 13\%), being higher to $C$ variability in the three tillage systems.

$\mathrm{CHw}$ evolution with time was similar to that of $\mathrm{CHt}$ during the 2 experiment years in CT, NT and VT, decreasing towards winter and increasing towards summer.

The interaction date $x$ tillage and the sources of variation, date and tillage, were highly significant $(\mathrm{P}<0.0001)$ for $\mathrm{CHw}$. The interaction explained $40.4 \%$ of $\mathrm{CHw}$ variability while the date factor contributed $41.9 \%$. These results show that
$\mathrm{CHw}$ behaved differently to $\mathrm{C}$ and $\mathrm{CH}$, in the sense that sampling time had a higher effect on $\mathrm{CHw}$ variability than on these variables.

Figure 3 shows that the relationships $\mathrm{C} / \mathrm{N}, \mathrm{CHt} / \mathrm{C}$ and $\mathrm{CHw} / \mathrm{C}$, which represent in some sense the quality of SOM compounds, evolved similarly with time in all treatments, not presenting significant differences $(P>0.05)$ between tillage systems for any sampling date.

The $\mathrm{C} / \mathrm{N}$ relationship varied, on average, between 10.5 and 10.9 , being similar in the three tillage systems on almost all dates; differences were not significant $(P>0.05)$. The variability of $\mathrm{C} / \mathrm{N}$ ratio throughout the two sampling years did
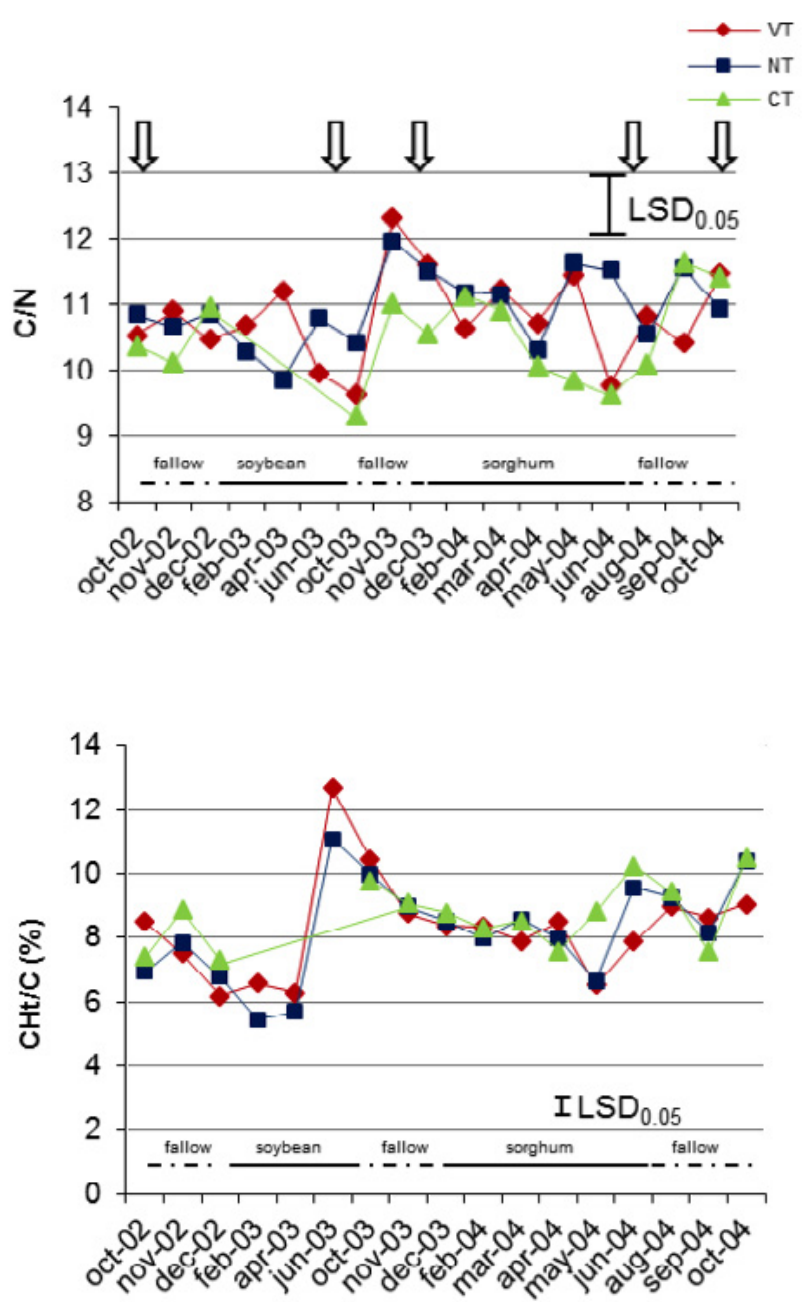


\section{Discussion}

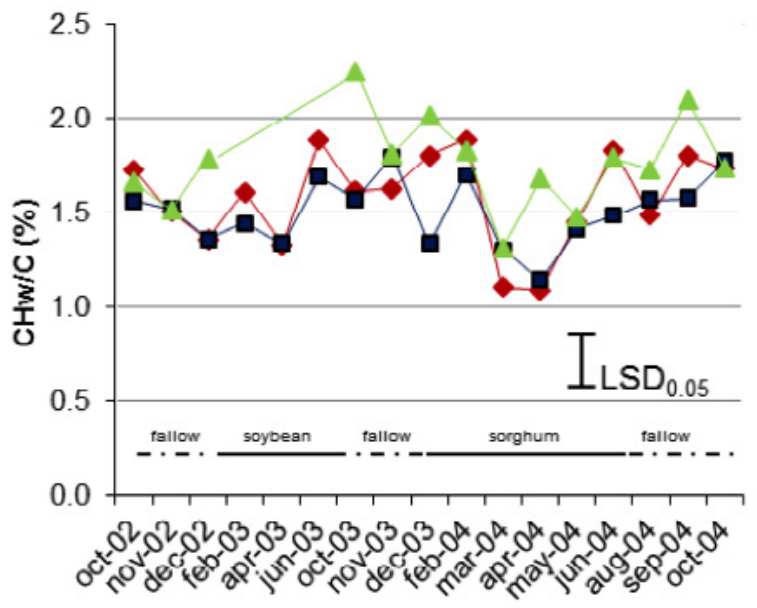

Figure 3. Evolution of a) $\mathrm{C} / \mathrm{N} \mathrm{b}$ ) $\mathrm{CHt} / \mathrm{C}$ and c) $\mathrm{CHw} / \mathrm{C}$ ratios in vertical tillage (VT), no-till (NT) and conventional tillage (CT). Arrows indicate a tilling practice.

not show differences between tillage systems, the variation coefficient being $5 \%$ in NT, $6 \%$ in VT and $6.4 \%$ in CT. C/N relationship evolved similarly during the 2 sampling years in all tillage systems, decreasing towards the winter and increasing towards summer (Figure 3).

The $\mathrm{CHt} / \mathrm{C}$ ratio oscillated between 8.2 and $8.7 \%$. There were significant differences $(p<0.05)$ found between tillage systems. The variability for CT, VT and NT was, respectively, $11.4,18$ and $19 \%$ and non-significant $(P>0.05)$. The $\mathrm{CHt} / \mathrm{C}$ relationship evolved a similar $\mathrm{C} / \mathrm{N}$ ratio, decreasing in winter and increasing in summer (Figure 3).

The ratio $\mathrm{CHw} / \mathrm{C}$ varied between 1.5 and $1.8 \%$, although significant differences $(P>0.05)$ between tilling practice were not found. The variation coefficients were 11.4, 13.4 and $15 \%$ for NT, CT and VT, respectively, and also not significant $(P>0.05)$. As well as $\mathrm{C} / \mathrm{N}$ and $\mathrm{CHt} / \mathrm{C}$ ratios, $\mathrm{CHw} / \mathrm{C}$ showed the same annual fluctuation (Figure 3), increasing in summer and decreasing in winter.
Contents of most analyzed SOM fractions were higher in the first $10 \mathrm{~cm}$-depth of the no-tilled than in the tilled soils for most of the sampling dates. These results also agree with those of previous studies performed in this region (Alvarez et al. 2017; Buschiazzo et al. 1996a; Díaz-Zorita et al. 2002) and in other parts of the world (BlancoMoure et al. 2011; Hu et al. 1995; GonzálezPrieto et al 2013; Raphael et al. 2016; Selles et al. 1999). The larger accumulation of organic residues in NT than in the other tillage systems, particularly in $\mathrm{CT}$, is explained on the basis of the superficial accumulation of SOM in NT and by the higher turnover and mineralization that occur in CT and VT.

The lower SOM content of CT was attributed to the more aggressive tillage practices that induced SOM oxidation and the turnover of residues in a wider soil volume than in VT. In general, differences between tillage systems may be explained on the basis of the different mineralization and distribution patterns of SOM in surface horizons (Díaz-Raviña et al. 2005).

Differences of $\mathrm{C}$ and $\mathrm{N}$ contents between NT and the other two tillage systems were smaller than those found by Alvarez and Lavado (1998) who measured differences ranging from 42 to $50 \%$ in soils of the Argentinean Rolling Pampas. These larger differences can be attributed to the longer period with no-till (12 years), the shallower sampling depth $(0-5 \mathrm{~cm})$ and the moister conditions of the Alvarez and Lavado (1998) study than in our experiment (6 years and $10 \mathrm{~cm}$, respectively). An increase of $\mathrm{C}$ as a function of time has been demonstrated in no-till systems, mainly in the first soil centimeters, due to the larger amounts of plant residues on the soil surface (Buschiazzo 2006) as well as by its high turnover and mineralization, the accumulation of organic matter being the predominant process.

$P$ contents were also higher in NT than in the other two tillage systems but differences were higher (26 to $32 \%$ ) than for the other analyzed SOM compounds. The larger accumulation of $P$ in NT, in comparison to the other analyzed SOM compounds, could be a product not only 
of the high accumulation of $\mathrm{P}$ compounds in the plant residues left on the soil surface by this tillage system, but also of their low solubility and mobility within the soil (Selles et al. 1999; DíazZorita and Grove 2002).

Temporal variations of $\mathrm{C}$ and $\mathrm{N}$ had similar tendencies, being higher in CT than in both NT and VT.

The lower temporal variability of $\mathrm{P}$ than that of $\mathrm{C}$ and $\mathrm{N}$ in all tillage systems indicates a low influence of tillage practices on this fraction. This agrees with results of Dick (1983) and Stevenson (1986) who found that $\mathrm{N}$ and C contents were more variable with cultivation than P. Stevenson (1986) observed that C, N and P decreased due to cultivation, even though the extent of this decrease was lower for $\mathrm{P}$.

$\mathrm{CHt}$ and $\mathrm{CHw}$ showed similar variation coefficients with time in all tillage systems, this trend being different to that of the other analyzed organic compounds which varied at different rates in each tillage system. These results indicate that the more stable organic compounds ( $\mathrm{C}, \mathrm{N}$ and $\mathrm{P}$ ) were more affected by tillage than by the environmental conditions, while the more labile fractions $(\mathrm{CHt}$ and $\mathrm{CHw}$ ) were affected by both, tillage operations and short term temperature or humidity changes. It is known that $\mathrm{CHt}$ and $\mathrm{CHw}$ are much more variable with time than $\mathrm{C}$ (Conen and Leifeld 2014; Conen et al. 2011; Gregorich et al. 1994; Haynes 1999; Kalbitz et al. 2003; Martín et al. 2011) because their formation depends on the activity of microorganisms that produce simple sugars, cellulose and hemicellulose from plant debris (Tisdall and Oades 1982; Gregorich et al. 1994). The amounts of these compounds are highly variable with time, depending on crops and tillage practices. It is also known that tillage operations produce the disruption of aggregates, releasing the protected SOM (Kristensen et al. 2000). This process may have been the cause of the variation of these organic compounds in CT and VT. However, as the higher variation of $\mathrm{CHt}$ in NT cannot be explained on the basis of tillage operations, this may be cause mainly by the environmental conditions.
All organic matter fractions increased in spring and summer and decreased in the fall and winter in NT and VT. These results were unexpected as it is known that the more labile fractions increase in agreement with a decrease of the more stable (Aubert et al. 2005). These results are partially in agreement with those of Hishi et al. (2004) who found that the carbohydrate concentration peaked in spring but also in the fall, but are contradictory with those of Xie and Steinberger (2001) who found that the total organic carbon contents exhibited the highest levels in fall and the lowest in summer.

Neither $\mathrm{C}$ nor $\mathrm{N}$ or $\mathrm{P}$ were related with any climatic variable. These results do not agree with findings of Alvarez and Lavado (1998) and Hevia et al. (2003) who showed that C contents decreased when mean temperatures increased. Differences with our results are probably due to the fact that these authors evaluated different soils under different climatic conditions in a given time, while our results were obtained from a single soil in different moments and tillage conditions.

The positive correlation of $\mathrm{CHt}$ with the inverse of the monthly mean temperature (1/MMT) in VT and NT $(P<0.05)$ and the lack of a correlation of $\mathrm{CHt}$ with the monthly rainfall, indicates that this fraction was affected negatively by temperature rather than by precipitation. These results do not agree with those of Hu et al. (1997) who found that the formation of carbohydrates depends on the activity of several organisms, particularly fungi, which increase their activity with higher temperatures. Results partially agree with those of Amelung et al. (1997) who found that polysaccharides tend to increase with rainfall and to decrease with higher temperatures.

The $\mathrm{C} / \mathrm{N}, \mathrm{CHt} / \mathrm{C}$ and $\mathrm{CHw} / \mathrm{C}$ relationships showed similar trends in the three tillage systems, with no differences between them for all sampling dates. These results indicate that tillage systems changed the amount but not the quality of SOM. 


\section{Conclusions}

Contents of stable ( $\mathrm{C}, \mathrm{N}$ and $\mathrm{P}$ ) and labile organic fractions ( $\mathrm{CHt}$ and $\mathrm{CHw}$ ) were higher in no-till (NT) than in tillage systems including soil removal (VT and CT) for most sampling dates.

All organic compounds were less variable with time in tillage systems with less soil disturbance, nevertheless, under these management conditions, the more labile fractions still varied as a function of short term changes of air temperature.

Under tillage systems including soil disturbances, the most stable fractions tended to decrease and the more labile to increase with time. This was attributed to the transformation of the more stable into the more labile fractions, possibly due to the aggregate disruption produced by tillage, which mineralized the protected SOM.

$P$ was the less variable organic compound, even under the highest disturbing tillage conditions (CT).

$\mathrm{C} / \mathrm{N}, \mathrm{CHt} / \mathrm{C}$ and $\mathrm{CHw} / \mathrm{C}$ ratios evolved similarly in all tillage systems, not presenting significant differences between tillage practices at each sampling time over the two year study. This means that tillage systems change the amount but not the quality of SOM.

\section{Acknowledgements}

Authors wish to thank A. Martín for collaborating with the carbohydrates methodology and R. Basanta for the Portuguese translation of the abstract.

\section{REFERENCES}

- Alvarez R, Lavado RS. 1998. Climate, organic matter and clay content relationships in the Pampa and Chaco soils, Argentina. Geoderma 83:127-141.

- Alvarez R, Steinbach HS, De Paepe JL. 2017. Cover crops effects on soils and subsequent crops in the pampas: a meta-analysis. Soil Till Res. 170:53-65.

- Amelung W, Flach KW, Zech W. 1997. Climate effects on soil organic matter composition in the Great Plains. Soil Sci Soc Am J. 61:115-123.

- Aubert M, Bureau F, Vinceslas-Akpa M. 2005. Sources of spatial and temporal variability of inorganic nitrogen in pure and mixed deciduous temperate forest. Soil Biol Biochem. 37:67-79.

- Blanco-Moure N, Gracia R, Bielsa, López MV. 2011. Long-term effects of no tillage on soil organic matter fractions in rainfed Aragon (NE) Spain. Spanish J Soil Sci. 1(1):116-121.

- Bono A, Alvarez R, Buschiazzo DE, Cantet RJC. 2008. Tillage effects on soil carbon balance in a semiarid agroecosystem. Soil Sci Soc Am J. 72:1140-1149.

- Bremner JM, Mulvaney CS. 1982. Nitrogen total. In: Page AL, Miller RH, Keeney DR, editors. Methods of Soil Analysis. Part 2. 2nd ed. Wisconsin: ASA. p. 595-624.

- Buschiazzo DE. 2006. Management systems in southern South America. In: Peterson GA, Unger PW, Payne WA, editors. Dryland Agriculture. 2nd ed. Wisconsin: ASA/ CSSA/SSSA. p. 395-426.

- Buschiazzo DE, Panigatti JL, Unger P. 1999a. Effects of tillage systems on soil properties and crop productivity in the semiarid Argentinian Pampas. Soil Till Res. 49:105116.

- Buschiazzo DE, Zobeck TM, Aimar SB. 1999b. Wind erosion in loess soils of the semiarid Argentinean Pampas. Soil Sci. 164:133-138.

- Conen F, Leifeld J. 2014. A new facet of soil organic matter. Agric Ecosyst Environ. 185:186-187.

- Conen F, Morris CE, Leifeld J, Yakutin MV, Alewell C. 2011. Biological residues define the ice nucleation properties of soil dust. Atmos Chem Phys. 11:9643-9648.

- Davidson EA, Janssens IA. 2005. Temperature sensitivity of soil carbon decomposition and feedbacks to climate change. Nature 440:165-173.

- Di Rienzo JA, Balzarini M, Casanoves F, González L, Tablada M, Robledo CW. 2002. Infostat/Professional version 1.1.

- Díaz-Raviña, Bueno J, González-Prieto SJ, Carballas T. 2005. Cultivation effects on biochemical properties, C storage and ${ }^{15} \mathrm{~N}$ natural abundance in the $0-5 \mathrm{~cm}$ layer of an acidic soil from temperate humid zone. Soil Till Res. 84:216-221. 
- Díaz-Zorita M, Duarte GA, Groove JH. 2002. A review of no-till systems and soil management for sustainable crop production in the subhumid and semiarid Pampas of Argentina. Soil Till Res. 65:1-6.

- Díaz-Zorita M, Groove JH. 2002. Duration of tillage management affects carbon and phosphorus stratification in phosphatic Paleudalfs. Soil Till Res. 66:165-174.

- Dick WA. 1983. Organic carbon, nitrogen and phosphorus concentrations and $\mathrm{pH}$ in soil profiles as affected by tillage intensity. Soil Sci Soc Am J. 47:102107.

- Doutre DA, Hay GW, Hood A, Vanloon GW. 1978. Spectrophotometric methods to determine carbohydrates in soil. Soil Biol Biochem. 10:457-462.

- Fröhlich-Nowoisky J, Burrows SM, Xie Z, Engling G, Solomon PA, Fraser MP, Mayol-Bracero OL, Artaxo P, Begerow D, Conrad R, Andreae MO, Després VR, Pöschl U. 2012. Biogeography in the air: Fungal diversity over land and oceans. Biogeosciences 9:1125-1136.

- Gili AA. 2012. Modelación de la variación espacial de variables edáficas y su aplicación en el diseño de planes de muestreo de suelos. PhD Thesis. National University of Cordoba. $190 \mathrm{p}$.

- González-Prieto S, Díaz-Raviña M, Martín A, LópezFando C. 2013. Effects of agricultural management on chemical and biochemical properties of a semiarid soil from central Spain. Soil Till Res. 134:49-55.

- Gregorich EG, Carter MR, Angers DA, Monreal CM, Ellert BH. 1994. Towards a minimum data set to assess soil organic matter quality in agricultural soil. Can J Soil Sci. 74:367-385

- Haynes RJ. 1999. Labile organic matter fractions and aggregate stability under short-term, grass-based leys. Soil Biol Biochem. 31:1821-1830.

- Haynes RJ. 2005. Labile organic matter fractions as central components of the quality of agricultural soils: An Overview. Adv Agron. 85:221-268.

- Hevia GG, Buschiazzo DE, Hepper EN, Urioste AM, Antón EL. 2003. Organic matter in size fractions of soils of the semiarid Argentina. Effects of climate, soil texture and management. Geoderma 116:265-277.

- Hishi T, Hirobe M, Tateno R, Takeda H. 2004. Spatial and temporal patterns of water-extractable organic carbon (WEOC) of surface mineral soil in cool temperate forest ecosystem. Soil Biol Biochem. 36:1731-1737.

- Hu S, Coleman DC, Beare MH, Hendrix PF. 1995. Soil carbohydrates in aggrading and degrading agroecosystems: influences of fungi and aggregates. Agr Ecosyst Environ. 54:77-88.

- Hu S, Coleman DC, Carroll CR, Hendrix PF, Beare MH. 1997. Labile soil carbon pools in subtropical forest and agricultural ecosystems as influenced by management practices and vegetation types. Agr Ecosyst Environ. 65:69-78.
- INTA, Gobierno de La Pampa, UNLPam. 1980. Inventario de los Recursos Naturales de la Provincia de La Pampa. Buenos Aires: Instituto Nacional de Tecnología Agropecuaria. $487 \mathrm{p}$.

- Inzaurralde RC, Rosenberg NJ, Lal R. 2001. Mitigation of climate change by soil carbon sequestration: Issues of science, monitoring and degraded lands. Adv Agron. 70:1-75.

- Kaila A. 1962. Determination of total organic phosphorus in samples of mineral soils. J Agr Sci Finland 34:187-196.

- Kalbitz K, Schwesig D, Schmerwitz J, Kaiser K, Haumanier L, Glaser B, Ellerbrock R, Leinweber P. 2003. Changes in properties of soil-derived dissolved organic matter induced by biodegradation. Soil Biol Biochem. 35: 1129-1142

- Kristensen HL, McCarty GW, Meisinger JJ. 2000. Effects of soil structure disturbance on mineralization of organic soil nitrogen. Soil Sci Soc Am J. 64:371-378.

- Lal R. 2004. Soil carbon sequestration to mitigate climate change. Geoderma 123:1-22.

- Lang R. 1920. Verwitterung und Bodenbildung als Einführung in die Bodenkunde. Schweitzerbart'sche Verlag. Cited by Buol SW, Hole FD, McCracken RJ. 1983. Génesis y clasificación de suelos. Stuttgart, Germany: Trillas.

- Leifeld J. 2006. Soil as sources and sinks of greenhouses gases. In: Frossad E, Blum WEH, Warkentin BP, editors. Function of soils for Human Societies and the Environment. Special Publications 266. London: Geological Society. p. 23-44.

- Martín A, Carballas T, Díaz-Raviña M. 2011. Seasonal changes in the carbohydrate pool of an Atlantic forest soil under different vegetation. Spanish J Soil Sci. 1(1):38-53.

- McLean EO. 1982. Soil pH and lime requirement. In: Page AL, Miller RH, Keeney DR, editors. Methods of Soil Analysis. Part 2. 2nd ed. Wisconsin: ASA. p. 199-224

- Moscatelli G, Puentes I. 1996. Caracterización edáfica de la región. In: Buschiazzo DE, Panigatti JL, Babinec FJ, editors. Labranzas en la Región Semiárida Argentina. INTA. p. 19-30.

- Nelson RE. 1982. Carbonate and gypsum. In: Page AL, Miller RH, Keeney DR, editors. Methods of Soil Analysis. Part 2. 2nd ed. Wisconsin: ASA. p. 181-197.

- Oertel C, Matschullat J, Zurba K, Zimmermann F, Erasmi S. 2016. Greenhouse gas emissions from soils-A review. Chemier der Erde - Geochemistry 76(3):327-352.

- Post WM, Kwon KC. 2000. Soil carbon sequestration and land-use change: processes and potential. Global Change Biol. 6(3):317-328.

- Pugget P, Angers DA, Chenu C. 1999. Nature of carbohydrates associated with water-stable aggregates of two cultivated soils. Soil Bio Biochem. 31:55-63. 
- Raphael JPA, Calonego JC, Milori DMBP, Rosolem CA. 2016. Soil organic matter in crop rotations under no-till. Soil Till Res. 155:45-53.

- Schlichting E, Blume HP, Stahr K. 1995. Bodenkundliches Praktikum. Blackwell Wissenschafts. $225 p$.

- Selles F, McConkey BG, Campbell CA. 1999. Distribution and forms of $P$ under cultivator -and zero-tillage for continuous-and fallow-wheat cropping systems in the semi-arid Canadian prairies. Soil Tillage Res. 51:47-59.

- Soon YK, Arshad MA, Haq A, Lupwayi N. 2007. The influence of 12 years of tillage and crop rotation on total and labile organic carbon in a sandy loam soil. Soil Till Res. 95:68-46.

- Stevenson FJ. 1986. Cycles of soil. New York: Wiley and Sons, Inc. 380 p.

- Tisdall JM, Oades JM. 1982. Organic matter and water stable aggregates in soils. J Soil Sc. 33:14-163.

- Walkley Y, Black IA. 1934. An examination of the Degrjareff method for determining soil organic matter and a proposed modification of the chromic acid titration method. Soil Sci. 37:29-38.

- Xie G, Steinberg J. 2001. Temporal patterns of C and N under shrub canopy in a loessial soil desert ecosystem. Soil Bio Biochem. 33:1371-1379. 